\title{
Analisis Penggunaan Cerita Rakyat Bengkulu Dalam pembelajaran Retorika/Komunikasi Massa
}

\author{
Rio Kurniawan, Didi Yulistyo \\ Fakultas Pendidikan Bahasa Universitas Bengkulu \\ Jl. WR. Supratman, Kandang Limun \\ Kurniawan22rio@yahoo.com
}

\begin{abstract}
Abstrak: Tujuan artikel ini adalah untuk mengetahui sejauh mana efektifitas penggunaan cerita rakyat bengkulu dalam pembelajaran retorika. Penelitian ini menggunakan pendekatan kualitatif dengan metode deskriptif. Secara deskriptif digunakan untuk mengambarkan kondisi pembelajaran retorika menggunakan cerita rakyat bengkulu pada mahasiswa kelas A semester $\mathrm{V}$ program studi Pendidikan Bahasa Indonesia FKIP Universitas Bengkulu, tahun ajaran 2016/2017. Berdasarkan hasil penelitianAktivitas mahasiswa menunjukkan perubahan yang positif, lebih tertarik dan antusias dalam pembelajaran keterampilan retorika/komunikasi massa dengan menggunakan cerita rakyat.Penggunaan cerita rakyat dapat meningkatkan keterampilan retorika/komunikasi massa. Hal ini dapat dilihat nilai dan ketuntasan belajar mahasiswa yang mengalami peningkatan. Hasil analisis data pada saat pembelajaran keterampilan retorika/komunikasi massa dengan menggunakan cerita rakyat, diperoleh data; sebanyak 21 mahasiswa memperoleh nilai diatas 70 dan ketuntasan belajar 90,84\%.
\end{abstract}

Kata Kunci: retorika, komunikasi massa, cerita rakyat

Abstract: The purpose of this study is to trace the extent of the use of Bengkulen folklore in the process of teaching and learning rhetorical subject. The study is a descriptive research which tries to portray the exercise of teaching rhetorical subject in which Bengkulen folklore is included. This study applies qualitative approach. The research subject deals with the fifth semester students of class $A$ from the study program of Indonesian Language Teaching (FKIP) of Bengkulu University in the academic year of 2016-2017. The study results in that student activities change into positive direction in learning by folklore. The application of folklore to the students can improve their skill in rhetoric or public communication. It can be seen from the grades they achieve and the extent of their finishing the 
86 | ESTETIK, Vol. 1 No. 1, Juni 2018

ISSN 2622-1810 (p) 2622-1829 (e)

subject. Based on the data analyzed, the result shows that there 21 students who receive grade up 70 and their fulfillment in learning reaches $90,84 \%$.

Keywords: rhetoric, public communication, folklore

\section{Pendahuluan}

Pada hakikatnya setiap tahun haruslah terjadi peningkatan dalam bidang akademik, maka dari itu diperluakan beberapa upaya untuk mewujudkan hal tersebut. Salah satunya dengan kegiatan penelitian yang berhubungan langsung dengan aspek akademik. Sejalan dengan pernyataan diatas, penelitian yang akan dilakukan ini merupakan bentuk implikasi dari hal tersebut. Dengan harapan ini menjadi salah satu tanggung jawab dosen dalam mengembang tri dharma perguruan tinggi. yang menjadi fokus penelitian ini adalah penggunaan cerita rakyat Bengkulu sebagai bahan materi pembelajaran komunikasi massa. Pada program studi pendidikan bahasa indonesia ditawarkan mata kuliah komunikasi massa dengan kode IND-2555 dengan bobot 2 SKS. Pada penelitian ini hakikatnya yang diteliti adalah kemampuan retorika sebab kemampuan berkomunikasi massa masih satu rumpun dengan kemampuan retorika

Karya sastra adalah sebuah hasil imaji seorang pengarang yang berusaha menceritakan kisah tentang kehidupan yang berada disekitar beliau. Salah satu bentuk hasil karya sastra adalah cerita rakyat. cerita rakyat adalah salah satu bentuk karya sastra prosa lama yang isinya berupa cerita, kisah, dongeng maupun sejarah. Cerita rakyat sebagai sebuah karya fiksi yang menawarkan sebuah dunia, dunia yang berisi kehidupan yang didamba-dambakan.

Pelajaran retorika pada umumnya, hanya menjadi sebuah kewajiban mahasiswa dalam menjalani pendidikan di universitas. Banyak yang beranggapan, dari kecil kita sudah bisa berbicara, kenapa mesti belajar retorika lagi yang isinya tak beda dengan keterampilan berbicara . Pendapat yang demikian sangatlah disayangkan, sebab retorika atau keterampilan berbicara, bukan hanya mengajarkan hakikat berbicara, tetapi lebih dari itu. Pembelajaran retorika mengajarkan kita tentang adat-istiadat, norma dan sopan-santun dalam kehidupan. 
Pada era Yunani Kuno, kemampuan retorika merupakan sebuah hal yang mesti dikuasai, sebab dengan menguasai retorika maka kita akan bisa menguasai dunia. Dari pendapat tersebut kita bisa membayangkan sejauh mana retorika, pada masa itu menjadi sebuah hal yang patut dipelajari.

Selain itu, pembelajaran retorika juga terkadang disajikan dengan cara yang monoton sehingga tidak bisa membuat peserta didik nyaman dalam pembelajran tersebut. Hal ini berbanding lurus dengan kenyataan bahwa, masih banyak peserta didik khususnya mahasiswa program studi pendidikan bahasa Indonesia yang memiliki kemampuan retorika yang rendah.

Permasalahan ini muncul bukan hanya karena kemampuan dan motivasi belajar mahasiswa yang kurang, melainkan faktor situasi belajar yang kurang dari sebuah proses menyenangkan. Dalam hal ini kreativitas dosen pengampu mata kuliah retorika dalam mengelola pembelajaran mempunyai pengaruh yang sangat besar dalam meningkatkan hasil belajar mahasiswa.

Masalah yang akan diteliti yaitu, sejauh mana efektifitas penggunaan cerita rakyat bengkulu dalam pembelajaran retorika pada mahasiswa program studi Pendidikan Bahasa Indonesia FKIP Universitas Bengkulu. Sejalan dengan rumusan masalah penelitian di atas, tujuan penelitian ini, untuk mengetahui sejauh mana efektifitas penggunaan cerita rakyat bengkulu dalam pembelajaran retorika.

\section{Metode Penelitian}

Penelitian ini menggunakan pendekatan kualitatif dengan metode deskriptif. Secara deskriptif digunakan untuk mengambarkan kondisi pembelajaran retorika menggunakan cerita rakyat bengkulu pada mahasiswa semester V program studi Pendidikan Bahasa Indonesia FKIP Universitas Bengkulu, tahun ajaran 2016/2017. Tempat pelaksanaan penelitian di semester V Prodi Pendidikan Bahasa Indonesia FKIP Universitas Bengkulu. Penelitian ini dilaksanakan pada semester ganjil tahun ajaran 2016/2017 selama tujuh bulan dari bulan Maret s.d September 2017. 
ISSN 2622-1810 (p) 2622-1829 (e)

Data dan sumber data penelitian ini yaitu mahasiswa semester $\mathrm{V}$ program studi Pendidikan Bahasa Indonesia FKIP Universitas Bengkulu, tahun ajaran 2016/2017, yang mengambil mata kuliah retorika. Pengumpulan data yang diperlukan terkait dengan penelitian ini menggunakan lembar observasi terhadap kegiatan pembelajaran retorika dengan menggunakan cerita rakyat bengkulu dan teknik tes, yaitu menguji kemampuan berbicara mahasiswa.

Alat pengumpul data peneletian ini yaitu, tes pembelajaran retorika menggunakan cerita rakyat bengkulu pada mahasiswa semester $\mathrm{V}$ program studi Pendidikan Bahasa Indonesia FKIP Universitas Bengkulu, tahun ajaran 2016/2017. Data dari hasil tes dikonfirmasikan dengan skala penilaian kategori skala empat, yakni istimewa (relevan), baik, cukup dan kurang, dengan deskripsi rentangan sebagai berikut:

\begin{tabular}{|c|c|c|}
\hline NO & SKALA PENILAIAN & KATEGORI \\
\hline 1 & $80-100 \%$ & Istimewa \\
\hline 2 & $70-79 \%$ & Baik \\
\hline 3 & $56-69 \%$ & Cukup \\
\hline 4 & $0-55 \%$ & Kurang \\
\hline
\end{tabular}

Standar kelulusan yang ditetapkan untuk mahasiswa yakni 70, sedangkan Ketuntasan Belajar yakni, 80 \%. Penilaian kemampuan berbicara dilakukan terhadap penampilan mahasiswa yang berupa kemampuan retorika. Aspek-aspek kemampuan retorika dengan skor sebagai berikut:
1. Tema
$40 \%$
2. Bunyi
$40 \%$
3. Penampilan $30 \%$

Tabel

Kriteria Penilaian Kemampuan Retorika 


\begin{tabular}{|c|c|c|c|c|}
\hline $\begin{array}{c}\text { UNSUR } \\
\text { PENILAIAN }\end{array}$ & SKOR & KATEGORI & KISI-KISI & KATEGORI \\
\hline Tema & $\begin{array}{l}31-40 \\
21-30 \\
11-20 \\
05-10\end{array}$ & $\begin{array}{l}A \\
B \\
C\end{array}$ & $\begin{array}{l}\text { Tema diungkapkan } \\
\text { dengan jelas, tidak } \\
\text { mengikuti pandangan } \\
\text { umum, antara judul } \\
\text { dan isi memiliki } \\
\text { keterkaitan, ide } \\
\text { tertata baik, memiliki } \\
\text { pesan. } \\
\text { Tema diungkapkan } \\
\text { dengan cukup jelas, } \\
\text { tidak mengikuti } \\
\text { pandangan umum, } \\
\text { judul dan isi ada } \\
\text { keterkaitan, ide masih } \\
\text { terorganisasi, } \\
\text { memiliki pesan. } \\
\text { Tema diungkapkan } \\
\text { dengan kurang jelas, } \\
\text { mengarah kepada } \\
\text { pandangan umum, } \\
\text { judul dan isi kurang } \\
\text { berhubungan, ide } \\
\text { terputus-putus, } \\
\text { permasalahan tidak } \\
\text { cukup, masih ada } \\
\text { pesan. Tak berisi, tak } \\
\text { ada substansi, tak ada } \\
\text { permasalahan }\end{array}$ & $\begin{array}{l}A= \\
\text { Istimewa } \\
B=\text { Baik } \\
C=\text { Cukup } \\
D=\text { Kurang }\end{array}$ \\
\hline Bunyi & $31-40$ & $\begin{array}{l}A \\
B\end{array}$ & $\begin{array}{l}\text { Terdapat estetika } \\
\text { tutur, memiliki } \\
\text { makna, pemilihan }\end{array}$ & $\begin{array}{l}A= \\
\text { Istimewa }\end{array}$ \\
\hline
\end{tabular}


ISSN 2622-1810 (p) 2622-1829 (e)

\begin{tabular}{|c|c|c|c|c|}
\hline & $\begin{array}{l}21-30 \\
11-20 \\
05-10\end{array}$ & $C$ & $\begin{array}{l}\text { kata dan ungkapan } \\
\text { kata tepat, harus ada } \\
\text { unsur musikalitas. } \\
\text { Terdapat estetika } \\
\text { tutur, pilihan kata } \\
\text { dan ungkapan } \\
\text { kadang-kadang } \\
\text { kurang tepat, tetapi } \\
\text { tidak mengganggu, } \\
\text { kurang } \\
\text { memperhatikan unsur } \\
\text { musikalitas. } \\
\\
\text { Terdapat estetika } \\
\text { tutur, kurang } \\
\text { memperhatikan } \\
\text { keindahan dan makna } \\
\text { tertentu, masih ada } \\
\text { musikalitas. } \\
\text { Susunan kata yang } \\
\text { tidak memperhatikan } \\
\text { keindahan dan makna } \\
\text { tertentu, tidak ada } \\
\text { musikalitas. }\end{array}$ & $\begin{array}{l}B=\text { Baik } \\
C=\text { Cukup } \\
D=\text { Kurang }\end{array}$ \\
\hline Penampilan & $\begin{array}{l}25-30 \\
20-24 \\
15-19 \\
05-14\end{array}$ & $A$ & $\begin{array}{l}\text { Pencitraan terasa } \\
\text { kuat, membangkitkan } \\
\text { tanggapan. } \\
\text { Pencitraan terasa, } \\
\text { kurang } \\
\text { membangkitkan } \\
\text { tanggapan. }\end{array}$ & $\begin{array}{l}A= \\
\text { Istimewa } \\
B=\text { Baik } \\
C=\text { Cukup } \\
D=\text { Kurang }\end{array}$ \\
\hline
\end{tabular}




\begin{tabular}{|l|l|l|}
\hline & $\begin{array}{l}\text { Pencitraan agak } \\
\text { terasa, } \text { kurang } \\
\text { membangkitkan } \\
\text { tanggapan. }\end{array}$ \\
& \\
& Pencitraan tidak \\
& terasa, tidak \\
membangkitkan & \\
tanggapan. & \\
\hline
\end{tabular}

\section{Landasan Teoritik}

Cerita rakyat dalam dunia akademik lebih populer dengan sebutan folklor (folklore). Istilah ini berasal dari bahasa Inggris, folklore, yang pertama kali dikemukakan oleh sejarawan Inggris William Thoms dalam sebuah surat yang diterbitkan oleh London Journal pada tahun 1846 (George, 1995). Folklor berkaitan erat dengan mitologi.

Folklor atau derita rakyat sebagai sebuah karya fiksi yang menawarkan sebuah dunia, dunia yang berisi kehidupan yang didambadambakan. Dunia imajianasi ini dibentuk melalui berbagai unsur pembangun dan semua unsur tersebut disampaikan melalui media bahasa. Jadi bahasa sebagai media penghubung antara penulis dan pembaca.

Cerita rakyat Nusantara merupakan bagian dari folklore yang mendasari sebuah kebudayaan dalm kehidupan manusia yang diwariskan secara turun menurun dari generasi ke generasi. Cerita rakyat nusantara mempunyai ciri-ciri, yaitu:

1. anonim: pengarangnya tidak dikenal;

2. istana sentris: menceritakan tokoh yang berkaitan dengan kehidupan istana/kerajaan;

3. bersifat statis: tetap, tidak banyak perubahan;

4. bersifat komunal: menjadi milik masyarakat;

5. menggunakan bahasa klise: menggunakan bahasa yang diulangulang; 
ISSN 2622-1810 (p) 2622-1829 (e)

6. bersifat tradisional: meneruskan budaya/ tradisi/ kebiasaan yang dianggap baik;

7. bersifat didaktis: didaktis moral maupun didaktis religius (mendidik);

8. menceritakan kisah universal manusia: peperangan antara yang baik dengan yang buruk, dan dimenangkan oleh yang baik;

9. magis: pengarang membawa pembaca ke dunia khayal imajinasi yang serba indah.

Kata retorika berasal dari bahasa Yunani, rethor. Retorika adalah sebuah teknik pembujuk-rayuan secara persuasi untuk menghasilkan bujukan dengan melalui karakter pembicara, emosional atau argumen (logo).

Retorika merupakan konsep untuk menerangkan tiga seni penggunaan bahasa persuasi yaitu: etos, patos dan logos. Dalam artian sempit, retorika dipahami sebagai konsep yang berkaitan dan seni berkomunikasi lisan berdasarkan tata bahasa, logika dan dialektika yang baik dan benar untuk mempersuasi public dengan opini. Dalam artian luas, retorika berhubungan dengan diskursus komunikasi manusia.

Uraian sistematis retorika yang pertama diletakkan oleh orang

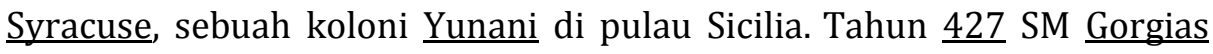
dikirim sebagai duta ke Athena. Negeri itu sedang tumbuh sebagai Negara yang kaya (Jalaluddin Rakhmat, 2011).

Selanjutnya, para pakar retorika lainnya adalah Isocrates dan Plato yang kedua-duanya dipengaruhi Georgias dan Socrates. Mereka ini berpendapat bahwa retorika berperan penting bagi persiapan seseorang untuk menjadi pemimpin. Plato yang merupakan murid utama dari Socrates menyatakan bahwa pentingnya retorika adalah sebagai metode pendidikan dalam rangka mencapai kedudukan dalam pemerintahan dan dalam rangka upaya mempengaruhi rakyat.

Puncak peranan retorika sebagai ilmu pernyataan antar manusia ditandai oleh munculnya Demosthenes dan Aristoteles dua orang pakar yang teorinya hingga kini masih dijadikan bahan kuliah di berbagai perguruan tinggi. Menurut Plato, retorika adalah seni para retorikan untuk menenangkan jiwa pendengar. Menurut Aristoteles, retorika 
adalah kemampuan retorikan untuk mengemukakan suatu kasus tertentu secara menyeluruh melalui persuasi.

Imran (https://blogmateri.wordpress.com/2015/02/12/makalahretorika-bahasa-indonesia/) menyatakan bahwa retorika didefinisikan sebagai seni membangun argumentasi dan seni berbicara (the art of constructing arguments and speechmaking). Dalam perkembangannya retorika juga mencakup proses untuk "menyesuaikan ide dengan orang dan menyesuaikan orang dengan ide melalui berbagai macam pesan".

Komunikasi massa adalah suatu proses dimana media menyebarkan pesan ke publik secara luas dan pada sisi lain diartikan sebagai bentuk komunikasi yang ditujukan pada sejumblah khalayak yang tersebar, heterogen, anonim, melalui media cetak atau elektronik sehingga pesan yang sama dapat diterima secara serentak dan sesaat.

Selanjutnya, Ciri- ciri dan karakteristik komunikasi massa meliputi sifat dan unsur yang tercakup didalamnya (Suprapto, 2006: 13). Adapun karakteristik komunikasi massa adalah:

1. Sifat komunikan, yaitu komunikasi massa yang ditujukan kepada khalayak yang jumblahnya relatif besar, heterogen, dan anonim. Jumblah besar yang dimaksudkan hanya dalam periode waktu yang singkat saja dan tidak dapat diukur, beberapa total jumblahnya. Bersifat heterogen berarti khalayak bersifat berasal dari latar belakang dan pendidikan, usia, suku, agama, pekerjaan,. Sehingga faktor yang menyatukan khalayak yang heterogen ini adalah minat dan kepentingan yang sama. Anonim berarti bahwa komunikator tidak mengenal siapa khalayaknya, apa pekerjaannya, berapa usianya, dan lain sebagainya;

2. Sifat media massa, yaitu serempak dan cepat. Serempak (Simultanety) berarti bahwa keserempakan kontak antara komunikator dengan komunikan yang demikian besar jumlahnya. Pada saat yang sama, media massa dapat membuat khalayak secara serempak dapat menaruh perhatian kepada pesan yang disampaikan oleh komunikator. Selain itu sifat dari media massa adalah cepat (rapid), yang berarti memungkinkan pesan yang disampaikan pada banyak orang dalam waktu yang cepat; 
ISSN 2622-1810 (p) 2622-1829 (e)

3. Sifat pesan, pesan yang disampaikan melalui media massa adalah bersifat umum (public). Media massa adalah sarana untuk menyampaikan pesan kepada khalayak, bukan untuk kelompok orang tertentu. Karena pesan komunikasi melalui media massa sifatnya umum, maka lingkungannya menjadi universal tentang segala hal, dan dari berbagai tempat di seluruh dunia. Sifat lain dari pesan melalui media massa adalah sejenak (transient), yaitu hanya untuk sajian seketika saja;

4. Sifat komunikator, karena media massa merupakan lembaga organisasi, maka komunikator dalam komunikasi massa, seperti wartawan, utradara, penyiar, pembawa acara, adalah komunikator yang terlembagakan. Media massa merupakan organisasi yang rumit, pesan-pesan yang disampaikan kepada khalayak adalah hasil kerja kolektif, oleh sebap itu, berhasil tidaknya komunikasi massa ditentukan oleh berbagai faktor yang terdapat dalam orginisasi massa.

Menurut Cangara, komunikasi tidak hanya diartikan sabagai pertukaran berita atau pesan, tetapi juga sebagai kegiatan individu dan kelompok mengenai pertukaran data, fakta, dan ide (Winardono, 2006: 57). Komunikasi massa dapat berfungsi untuk:

1. Informasi, yaitu kegiatan untuk mengumpulkan, menyimpan data, fakta, opini, pesan, komentar, sehingga orang bisa mengetahui keadaan yang sesungguhnya;

2. Sosialisasi, yakni menyediakan dan mmengajarkan ilmu pengetahuan bagaimana orang bersikap sesuai dengan nilai-nilai yang ada, serta bertindak sebagai anggota masyarakat secara efektif;

3. Motivasi, mendorong orang untuk mengikuti kemajuan orang lain melalui apa yang mereka baca, lihat, dengar, melalui media massa;

4. Bahan diskusi, yaitu menyediakan informasi untuk mencapai persetujuan dalam hal perbedaan pendapat mengenai hal-hal yang menyangkut orang banyak;

5. Pendidikan, yaitu dengan menyajkan informasi yang mengandung nilai edukasi, sehingga membuka kesempatan untuk memperoleh pendidikan secara informal; 
6. Memajukan kebudayaan, media massa menyebarluaskan hasilhasil kebudayaan melalui pertukaran siaran radio, televisi, atau media cetak. pertukaran ini memungkinkan penigkatan daya kreativitas guna memajukan kebudayaan nasional masingmasing negara serta memperkuat kerjasama masing-masing negara;

7. Hiburan, media massa adalah sarana yang banyak menyita waktu luang semua golongan usia, dengan difungsikannya sebagai alat hiburan dalam rumah tangga. Sifat estetikanya dituangkan dalam bentuk lagu, lirik, bunyi, gambar, dan bahasa, membawa orang pada situasi menikmati hiburan seperti halnya hiburan lain;

8. Integrasi, yaitu banyaknya negara-negara didunia dewasa ini diguncang oleh kepentingan-kepentingan tertentu, karena perbedaan etnis dan ras. Komunikasi sepert satelit dapat digunakan untuk menghubungkan perbedaan-perbedaan itu dalam memupuk dan memperkokoh persatuan dan kesatuan bangsa.

Sesuai dengan desain penelitian maka alur penelitian ini dapat diuraikan sebagaimana dalam diagram berikut:

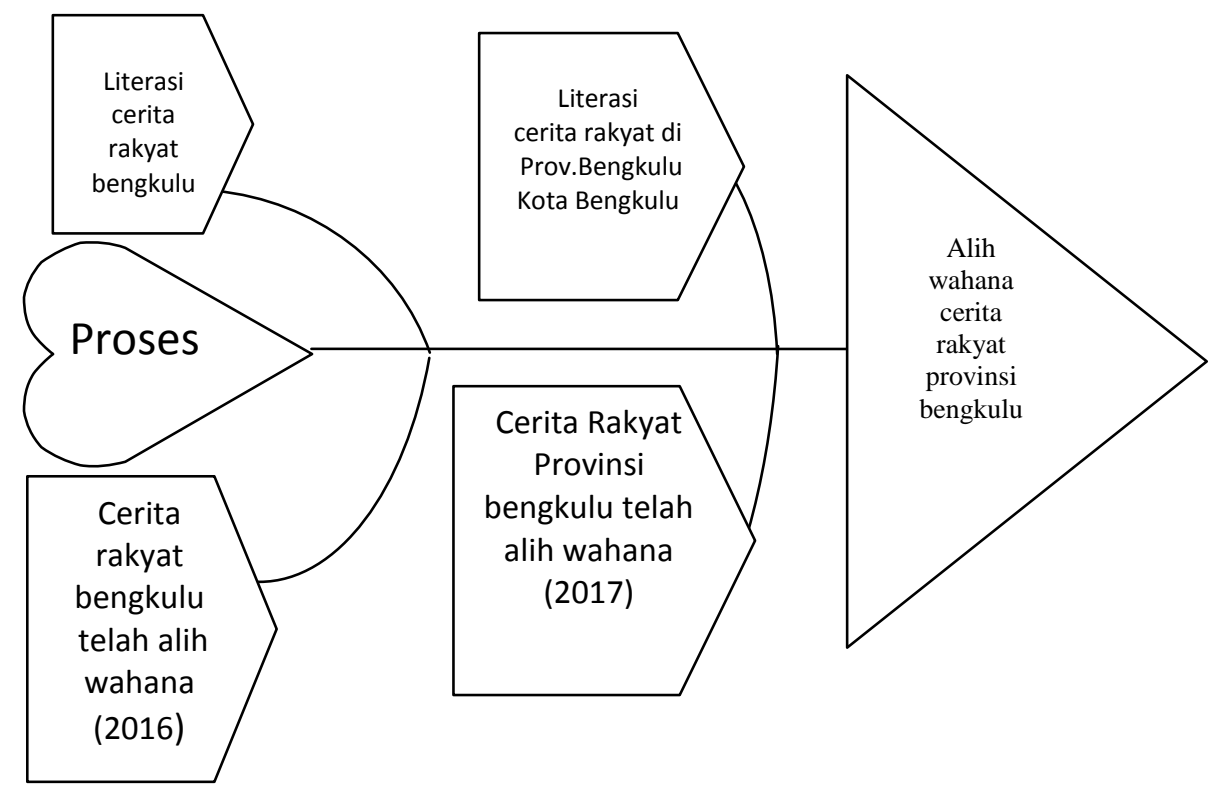


96 | ESTETIK, Vol. 1 No. 1, Juni 2018

ISSN 2622-1810 (p) 2622-1829 (e)

\section{Hasil Temuan dan Pembahasan}

Kegiatan awal dalam penelitian ini, peneliti melakukan persiapan, yang meliputi menyusun skenario pembelajaran, menyusun rencana pelaksanaan perkuliahan ,menyiapkan materi sesuai dengan kompetensi yang diajarkan.Pelaksanaan tindakan ini dilakukan dengan kegiatan sebagai berikut:

1. Dosen membuka pelajaran dan dilanjutkan dengan apersepsi;

2. Bertanya jawab tentang pengalaman mahasiswa berbicara di depan umum;

3. Menghubungkan pengalaman mahasiswa dengan materi yang akan dipelajari;

4. Menjelaskan kaidah yang tetap harus dipertahankan dalam retorika/komunikasi massa;

5. Bertanya jawab tentang pemahaman mahasiswa terhadap teknik retorika/komunikasi massa;

6. Mahasiswa diberi penguatan lagi tentang retorika/komunikasi massa;

7. Mahasiswa menulis konsep cerita rakyat dengan menggunakan pilihan kata yang sesuai;

8. Mahasiswa diberi kesempatan untuk meninjau kembali hasil tulisannya, terutama pilihan kata.

Pada saat KBM akan berlangsung, semua mahasiswa terlihat antusias untuk mengikuti pembelajaran hari itu. Pada waktu dosen menjelaskan materi pembelajaran mengenai teknik dan contoh retorika yang baik, semua mahasiswa terlihat dengan sungguh-sungguh memperhatikan. Setelah dosen menjelaskan ada beberapa mahasiswa yang bertanya. Mahasisswa yang lain ikut mendengarkan pertanyaan dari temannya. Dosen memberi kesempatan kepada mahasiswa untuk menjawab pertanyaan dari temannya. Dosen menjawab pertanyaan dari mahasiswa sembari memberikan penguatan.

Kegiatan berikutnya adalah proses evaluasi, mahasiswa diminta untuk berbicara di depan kelas dengan durasi tiga menit setiap orang. Dosen memberikan penilaian terhadap penampilan mahasiswa. 
Setelah pembelajaran berakhir dosen menutup kegiatan pembelajaran pada hari itu, semua pekerjaan mahasiswa dikumpulkan untuk dikoreksi. Setelah peneliti mengoreksi hasil tulisan mahasiswa dan menilai penampilan berbicara mahasiswa, ada beberapa hal yang perlu diketahui, yaitu:

1. Masih terdapat jarak antara tema dengan substansi penjelasan mengenai isi konsep cerita rakyat, sehingga terkesan ide belum tertata dengan baik;

2. Estetika tutur yang digunakan belum sempurna.

Hasil analisis data pada saat pembelajaran keterampilan retorika/komunikasi massa dengan menggunakan cerita rakyat, diperoleh data; sebanyak 21 mahasiswa memperoleh nilai diatas 70 dan ketuntasan belajar 90,84\%. Hal tersebut diperoleh dari empat kali uji coba yang dilakukan peneliti dan mitra. Karena dari hasil pengamatan dan penilaian kemampuan retorika mahasiswa, masih terdapat beberapa kelemahan dari kegiatan retorika yang dilakukan, sehingga peneliti dan mitra, terus melakukan perbaikan dari setiap proses pembelajaran.

Penataan ide dan estetika tutur yang masih dianggap terlalu lemah, oleh karena itu aspek tersebut menjadi fokus peneliti dalam perbaikan setiap tahapan penelitian. Peniliti memberikan contoh-contoh pilihan kata yang sesuai sehingga harapannya imajinasi pendengar serasi dengan isi atau tema cerita rakyat yang disampaikan. Sehingga kegiatan retorika yang dilakukan mahasiswa tadi sesuai dengan konsep retorika merupakan tiga seni penggunaan bahasa persuasi yaitu: etos, patos dan logos.

Estetika tutur ini juga harus mengacu kepada pilihan kata yang sesuai sebab pendengar bersifat heterogen, jadi kita tidak bisa sembarangan dalam memilih kata. Hal ini sejalan dengan pendapat pakar (Suprapto, 2006: 13) yang menyatakan bahwa salah satu karakteristik komunikasi massa adalah sifat komunikan, yaitu komunikasi massa yang ditujukan kepada khalayak yang jumblahnya relatif besar, heterogen, dan anonim. Jumlah besar yang dimaksudkan hanya dalam periode waktu yang singkat saja dan tidak dapat diukur, beberapa total jumlahnya. Bersifat heterogen berarti khalayak bersifat berasal dari latar belakang dan pendidikan, usia, suku, agama, pekerjaan. Sehingga faktor yang 
98 | ESTETIK, Vol. 1 No. 1, Juni 2018

ISSN 2622-1810 (p) 2622-1829 (e)

menyatukan khalayak yang heterogen ini adalah minat dan kepentingan yang sama. Anonim berarti bahwa komunikator tidak mengenal siapa khalayaknya, apa pekerjaannya, berapa usianya dan lain sebagainya.

\section{Simpulan}

Berdasarkan hasil penelitian, maka dapat disimpulkan bahwa aktivitas mahasiswa menunjukkan perubahan yang positif, lebih tertarik dan antusias dalam pembelajaran keterampilan retorika/komunikasi massa dengan menggunakan cerita rakyat. Selain itu, penggunaan cerita rakyat dapat meningkatkan keterampilan retorika/komunikasi massa. Hal ini dapat dilihat dari perolehan nilai dan ketuntasan belajar mahasiswa yang mengalami peningkatan.

\section{Daftar Rujukan}

Alwi, Hasan. 2002. Kamus Besar Bahasa Indonesia. Jakarta: Balai Pustaka.

Anggraeni, Nina (2012) Peningkatan Kemampuan Menulis Puisi Dengan Menggunakan Model Sugestopedia. http://repository.upi.edu/10745/ (Diunduh tanggal 23 Maret 2017)

Arikunto, Suharsimi. 1997. Dasar-dasar Evaluasi Pendidikan. Jakarta: Bumi Aksara.

Atmazaki. 1993. Pengantar Aprsesiasi Karya Sastra. Jakarta: Bumi Aksara.

B. Uno, Hamzah. 2008. Model Pembelajaran. Jakarta: Bumi Aksara.

Cangara, Havied. 2002. Pengantar Ilmu Komunikasi. Jakarta : Raja Grafindo Persada.

Djiwandono, S. 1996. Tes Bahasa dan Pengajaran. Bandung: ITB.

George, Robert A., Michael Owens Jones. 1995. Folkloristics: An Introduction, Indiana University Press.

Imran, Abi Adli. Retorika Bahasa Indonesia. https://blogmateri.wordpress.com /2015/02/12/makalah-retorika-bahasa-indonesia/ (Diunduh tanggal 23 Maret 2017)

Moleong, Lexy. 1998. Metodologi Penelitian Kualitatif. Bandung: PT Remaja Rosdakarya. 
Nababan, Sri Utari Subyakto. 1993. Metodologi Pengajaran Bahasa. Jakarta: Gramedia Pusataka Utama.

Nurgiyantoro, Burhan. 1987. Penilaian dalam Pengajaran Bahasa dan Sastra. Yogyakarta: BPFE

Nur, Moh. 2001. Pemotivasian Siswa untuk Belajar. Surabaya. University Press. Universitas Negeri Surabaya.

Poerwadarminta. 1985. Kamus Umum Bahasa Indonesia. Jakarta. Balai Pustaka.

Rakhmat, Jalaludin. 2009. Retorika Moderrn Pendekatan Praktis. Bandung: Remaja Rosdakarya.

Suprapto, Tommy. 2006. Pengantar Teori Komunikasi. Yogyakarta: Media Pressindo.

Tarigan, Henry Guntur. 2009. Metode Pengajaran Bahasa.bandung: Angkasa Bandung. 
100 | ESTETIK, Vol. 1 No. 1, Juni 2018

ISSN 2622-1810 (p) 2622-1829 (e) 